\title{
Memory Lane and Morality: How Childhood Memories Promote Prosocial Behavior
}

\section{Citation}

Gino, F., and S. Desai. "Memory Lane and Morality: How Childhood Memories Promote Prosocial Behavior." Journal of Personality and Social Psychology 102, no. 4 (2012): 743-758.

\section{Permanent link}

http://nrs.harvard.edu/urn-3:HUL.InstRepos:10996789

\section{Terms of Use}

This article was downloaded from Harvard University's DASH repository, and is made available under the terms and conditions applicable to Open Access Policy Articles, as set forth at http:// nrs.harvard.edu/urn-3:HUL.InstRepos:dash.current.terms-of-use\#OAP

\section{Share Your Story}

The Harvard community has made this article openly available.

Please share how this access benefits you. Submit a story.

\section{Accessibility}


Running Head: MEMORY LANE AND MORALITY

\author{
Memory Lane and Morality: \\ How Childhood Memories Promote Prosocial Behavior
}

Francesca Gino

Harvard University

Sreedhari D. Desai

Edmond J. Safra Center for Ethics

Harvard University

$\&$

University of North Carolina at Chapel Hill

The authors are thankful to Max Bazerman and Arthur Brief for their insightful comments on earlier drafts. The authors greatly appreciate the support and facilities of the CLER and of the Center for Decision Research at the University of North Carolina at Chapel Hill. This research was supported by a grant from the University Research Council URC at the University of North Carolina at Chapel Hill and by Harvard Business School. Please address correspondence concerning this article to fgino@ $\mathrm{hbs}$.edu. 


\begin{abstract}
Although research has established that autobiographical memory affects one's self-concept, little is know about how it affects moral behavior. We focus on a specific type of autobiographical memory: childhood memories. Drawing on research on memory and moral psychology, we propose that childhood memories elicit moral purity, which we define as a psychological state of feeling morally clean and innocent. In turn, heightened moral purity leads to greater prosocial behavior. In Experiment 1, participants instructed to recall childhood memories were more likely to help the experimenter with a supplementary task than were participants in a control condition, and this effect was mediated by moral purity. In Experiment 2, the same manipulation increased the amount of money participants donated to a good cause, and both implicit and explicit measures of moral purity mediated the effect. Experiment 3 provides further support for the process linking childhood memories and prosocial behavior through moderation. In Experiment 4, we find that childhood memories led to punishment of others' ethically-questionable actions. Finally, in Experiment 5, both positively-valenced and negatively-valenced childhood memories increased helping compared to a control condition.
\end{abstract}

Keywords: Autobiographical memory; Childhood; Ethics; Memories; Morality; Prosocial Behavior; Punishment; Purity 
Memories based on past experiences are an important part of our life as they help us create and maintain our identity (Brewer, 1986; Robinson, 1986). By sharing our past experiences with others and by listening to their memories we can build and strengthen social relationships (Bauer, Stennes, \& Haight, 2003). The recollection of past experiences that affect the development of "who we are" as individuals form our autobiographical memory (Baddeley, 1995; Brewer, 1986; Conway, 1990; Nelson, 1993; Robinson, 1992; Rubin, 1986).

Scholars have long displayed an interest in autobiographical memory (e.g., Colegrove, 1899; Galton, 1879; Miles, 1893), and have conducted insightful work from various perspectives (see Conway \& Pleydell-Pearce, 2000, and Fivush, 2011 for thorough reviews). Prior research has examined how this particular form of memory develops (e.g., Fivush, 1993; Nelson, 1993), what explains differences in accessibility and accuracy of past experiences (e.g., Conway, 1990, 1996; Conway \& Rubin, 1993), and the relationship between emotion or culture and autobiographical memories (e.g., Levine, Stein, \& Liwag, 1999; Han, Leichtman, \& Wang, 1998).

At any given moment, only a subset of our autobiographical memories are accessible or active in our mind, and that subset influences how we view ourselves at that moment (Markus \& Kunda, 1986; Markus \& Nurius, 1986; Sanitoso, Kunda, \& Fong, 1990). For instance, people who are asked to recall instances of past extraverted actions view themselves as more extraverted than those asked to recall instances of past introverted actions (Fazio, Effrein, \& Falender, 1981). Similar effects have also been shown in the case of one's own self-esteem (Jones, Rhodewalt, Berglas, \& Skelton, 1981) and perceived verbal skills (Sherman, Skov, Hervitz, \& Stock, 1981). Although research provides valuable insights into the nature of autobiographical memory and how it affects the self-concept, it offers less information about the impact of past memories 
on one's own sense of morality and subsequent behavior. The particular conceptions of the self that are active at a given time regulate and direct individuals' behavior (Bandura, 1989; Markus \& Ruvolo, 1989). So, if autobiographical memories elicit a sense of heightened morality and moral self-concept as we hypothesize, then they are likely to also impact subsequent behavior that is consistent with the activated and now salient self-concept.

In this paper, we focus on a specific type of autobiographical memory: the recollection of experiences related to one's own childhood. Drawing on research on autobiographical memory and on moral psychology, we argue that recalling childhood memories influences the extent to which we see ourselves as morally pure. We also suggest that this heightened sense of moral purity, in turn, leads to greater prosocial behavior (i.e., behavior that directly benefits others).

Across five experiments that employ various measures of prosocial behavior, we tested the relationship between childhood memories, moral purity and prosocial behavior.

\section{Moral Domains and Moral Purity}

Moral psychology research views morality as pertaining to five distinct moral domains (Haidt \& Graham, 2007; Haidt \& Joseph, 2004; see also Shweder, Much, Mahapatra, \& Park, 1997): harm/care, fairness/reciprocity, ingroup/loyalty, authority/respect and purity/sanctity. Moral domains refer to sets of principles, rules, and values that identify what is good and virtuous, and how individuals ought to behave (Horberg, Oveis, Keltner, \& Cohen, 2009). When a given behavior violates the rules of one of these moral domains, then people judge it as morally inappropriate or wrong. These five moral domains are universal: they are basic, innate domains of morality that are present in every culture (Horberg et al., 2009).

Of particular relevance for this paper is the domain of purity. This domain involves values, rules and principles regarding the protection of the sanctity of a person's body and soul 
(Haidt \& Graham, 2007; Haidt \& Joseph, 2004). It encompasses the belief that people should strive to live in a pure, sacred way: both their mind and their body should be clean, chaste and pure (Horberg et al., 2009). Behaviors that are inconsistent with these values and principles are thus impure and also immoral. So, for instance, behaviors that are profane, self-polluting, disgusting, hedonistic or ungodly are judged by people to be immoral (Haidt \& Joseph, 2007; Horberg et al., 2009; Rozin, Lowery, et al., 1999). Thus, in this framework, purity has moral significance, even if it may not be as high as that of other moral domains (Shweder et al., 1997).

Drawing on this research, we define moral purity as a psychological state that results from a person's view of the self as clean from a moral standpoint, and through which a person feels innocent and virtuous. Prior research on embodied moral cognition has demonstrated that physical purity is an effective metaphor for moral purity (Rozin, Millman, \& Nemeroff, 1986). Consistent with this metaphor, research has found that reminders of past moral transgressions enhance the desire for physical cleansing (Zhong \& Liljenquist, 2006), and that clean scents and clean environments promote virtuous behaviors (Liljenquist, Zhong, \& Galinsky, 2008, 2010). Prior work has also established that clothes of an evil person are considered physically repulsive (Rozin, Markwith, \& McCauley, 1994), and that disgust leads to harsher condemnations of moral violations (Haidt \& Hersh, 2001; Wheatley \& Haidt, 2005). More recently, building on these findings, Sherman and Clore (2009) found that people automatically associate morality and immorality with the colors white and black.

Here, we extend this research in three important ways. First, we provide a clear definition of moral purity and identify measures for this construct. Second, we examine a new, previously overlooked trigger of moral purity, namely one's own childhood memories. Third, we propose 
and demonstrate that the experience of moral purity is directly linked to moral behaviors (i.e., prosocial behaviors).

\section{Childhood Memories and Heightened Moral Purity}

Several scholars have demonstrated that remembering is a reconstructive process (Barlett, 1932; Hyman \& Pentland, 1996). When people are asked to recall a past experience, they do not retrieve the memory as a whole entity; rather, they construct the memory using the information available in their memory as well as related knowledge (e.g., Barclay \& DeCooke, 1988; Barlett, 1932; Neisser, 1982). In fact, scholars have suggested that, at times, information received after the event being recalled can erase or overwrite the original information (Loftus, 1979; Loftus, Donders, Hoffman, \& Schooler, 1989), leading individuals to create false memories.

In the case of childhood memories, people may recall specific events from their past (e.g., the first time they made a friend in preschool) but they may also include information regarding their general views about children and childhood (e.g., "children are innocent creatures"). When recalling their past experiences as a child, we propose, people may start thinking about childhood more generally. Even if they do not think about it explicitly, the concept of childhood will be activated in their mind. As a result, we suggest, these general views about childhood may color the psychological state people are in as they recall their experience as children. But what are the general views we have of childhood?

Across cultures, children are commonly viewed as innocent and pure human beings who are not tainted by vices or selfish motives (James, Jenks, \& Prout, 1998; Woodrow, 1999), and are regarded as little angels that adults have a duty to protect (Branscombe, Castle, Dorsey, Surbeck \& Taylor, 2000; Scott \& Watson-Brown, 1997). The words commonly used to refer to children, including "innocent creatures," "little angels," "flowers," or "divine creatures" mirror 
this view. In a similar vein, Froebel's metaphor of kindergarten, the "garden of children", portrays children as seedlings, in a state of natural goodness, to be nurtured and cared for during their development (Aries, 1962). This image of the child as innocent is constantly represented in the sentimental world of greeting cards, in the arts and literature, in religion, and it is also played out in the media portrayal of tragic events including children. When children are involved, the event is often characterized as something that has taken away children's innocence, as if innocence and purity are inherent characteristics of childhood (Woodrow, 1999).

These common associations between childhood and moral purity are not altogether surprising in light of the extensive work in developmental psychology suggesting that children indeed are often kind and fair (e.g., Bloom, in press; Hamlin, Wynn, \& Bloom, 2007; Warneken \& Tomasello, 2007). ${ }^{1}$ Considerable evidence indicates that prosocial behavior begins quite early in development (Kakavoulis, 1998; Vaish, Carpenter, \& Tomasello, 2009; see also Eisenberg, Fabes, \& Spinrad, 2006). From the age of two, prosocial behavior becomes a distinct behavior in children's behavioral repertoires, and also an important determinant of their growing social competence (Knafo \& Plomim, 2006; Persson, 2005). For example, research has found that children who are just four years old spontaneously try to comfort people in distress by caressing them or offering them a bottle or toy (Dunn \& Kendrick, 1979; Zahn-Waxler, Radke-Yarrow, \& King, 1979). If they perceive that someone is need of help, children of similar ages try to reach over and assist them (Warneken, Hare, Melis, Hanus, \& Tomasello, 2007). And if they witness someone behaving kindly toward others, they try to reward them (Hamlin et al., 2007; Jacob \& Dupoux, 2008).

\footnotetext{
${ }^{1}$ Although kindness and fairness are not the same constructs as moral purity, like purity, they belong to the domain of morality and are associated with moral goodness.
} 
Although these associations between childhood and moral purity exist in arts and religion across cultures, to date they have been not empirically studied. Research has consistently found that once a concept is activated, associated concepts (from traits to stereotypes to goals) are also triggered through spreading activation (Bargh, 1997; Neely, 1977). For instance, coldness and loneliness (Zhong \& Leonardelli, 2008) or darkness and aggression (Frank \& Gilovich, 1988) are examples of symbolic associations that are reciprocally related. The initial activation may occur because of a situational cue, such as an object, a word or a symbol in the surrounding environment (Bargh, 1994, 1997; Bargh, Chen, \& Burrows, 1996).

Here, we suggest that the initial activation occurs because of childhood memories: When people are asked to recall their past experiences as children, the concept of childhood is activated and, by association, it then triggers the concept of moral purity. In general, autobiographical memories influence one's sense of self (Bruner, 1986; Neisser, 1988). In the case of childhood memories, we propose, one's moral self-concept is likely to become more salient as a result of the association between the concept of childhood and that of moral purity. Thus, we hypothesize that recalling childhood memories increases individuals' perceived moral purity.

We propose that the association between childhood and moral purity that is triggered by childhood memories not only occurs explicitly (i.e., when the concept of childhood is activated people report feeling morally pure) but also implicitly (i.e., when the concept of childhood is activated, the concept of moral purity is also activated automatically in people's mind). An increasing number of studies have found evidence for the reciprocal and unconscious activation of symbolic associations, such as filth and sin (Liljenquist et al., 2010; Rozin et al., 1986), or white and pure (Sherman \& Clore, 2009). 
Congruent concepts are linked together in individuals' memory within a network of nodes. When one concept is activated (e.g., filth), this activation spreads along the network and results in the activation of related concepts (e.g., sin), and this spreading occurs automatically (Anderson, 1976, 1983; Collins \& Loftus, 1975). Across contexts, individuals are commonly not aware of the effect of the cue on the activation of the primed construct.

We suggest that childhood memories operate in the same way: When recalling memories from one's own past experiences as a child, the general concept of childhood will be activated. In turn, this concept will automatically activate the related construct of moral purity. In short, we expect that recalling childhood memories will automatically activate notions of moral purity.

\section{Childhood Memories, Moral Purity and Prosocial Behavior}

Over the last two decades, social psychology research has demonstrated the effects priming can have on behavior. Priming refers to the situational activation of mental constructs (Bargh et al., 1996; Bargh et al., 2001), and its effects on behavior are mainly driven by these constructs (Dijksterhuis \& Bargh, 2001). As explained by Fitzsimons, Chartrand, and Fitzsimons (2008: p. 22), "Constructs associated with the primed representation guide behavior through a direct perception-behavior link, when people's behavior mirrors a perceived construct." For instance, because individuals' mental representation of a library is linked to the construct "silence," when people are primed with the construct library through a picture, "silence" is also activated in their minds (as shown by Aarts \& Dijksterhuis, 2003). As a result, because of links to behavioral representations, the activated construct leads to an increased likelihood that the corresponding behavior will result (i.e., people will lower their voice when talking).

By the same token, to the extent that people's mental representation of childhood is linked to the construct "moral purity," when people are primed with the construct childhood as 
they recall and write about their childhood memories, "moral purity" will be activated in their minds. In turn, the activated construct of moral purity will lead to increased prosocial behavior since that behavior is consistent with a self-concept that is clean from any immoral concerns.

Recent evidence in moral psychology is suggestive of a link between moral purity and prosocial behavior. Research has demonstrated that feeling morally impure (e.g., because one hand-copied a first person account of unethical behavior) increases one's desire for physical cleanliness (Zhong \& Liljenquist, 2006). Related studies have focused on the inverse relationship (i.e., cleanliness $\rightarrow$ moral behavior) and have found that clean scents and visual cleanliness promote virtuous behaviors by increasing the tendency to reciprocate trust and to offer charitable help (Liljenquist et al., 2008, 2010).

Like other internal, psychological states that provide systematic input into complex moral judgments and behaviors (Greene \& Haidt, 2002; Haidt, 2001, 2003; Horberg, Oveis, \& Keltner, 2011), we expect moral purity to lead to prosocial behavior. Prosocial behavior refers to actions that people intentionally undertake in order to help or benefit others (Schwartz \& Bilsky, 1990), as in the case of helpful interventions (e.g., Batson, 1987; Cialdini et al., 1987), donations of time, blood or money (e.g., Frey \& Meier, 2004; Piliavin \& Callero, 1991), and volunteer work (e.g., Foster, Mourato, Pearce, \& Ozdemiroglu, 2001; Freeman, 1997).

Once the psychological state of moral purity is activated, people are likely to engage in behaviors that are consistent with a pure and morally clean self-concept. As we noted earlier, autobiographical memories tend to be self-representative such that we infer from them who we are and what our self-identity is (Bruner, 1986; Neisser, 1988). Once a given self-identity is activated, it guides our behavior in the current situation. Recalling childhood events activates the notion that we were once morally pure beings (since children, in general, are considered as such), 
and this attribute of purity serves to direct subsequent behaviors that are consistent with that selfidentity. Long-standing evidence in social psychology indicates that people strive for consistency within their attitudes, beliefs, and behavior (Festinger, 1957; Heider, 1958). The desire to behave consistently with one's own personal values, beliefs, or previous choices, is generally very strong and leads people to behave in ways that are consistent over time as in the case of compliance with requests consistent with a commitment we made in the past (Cialdini, 2001).

When moral purity is activated, people's moral self-concept is likely to be salient as well as their desire to remain morally clean. One way to realize this desire is to behave prosocially if given the opportunity. Thus, we expect moral purity triggered by childhood memories to lead to prosocial behavior. Furthermore, we expect moral purity to mediate the relationship between recalling childhood memories and prosocial behavior.

\section{Overview of Experiments}

Five experiments tested the hypothesis that childhood memories make people experience a sense of moral purity both consciously and unconsciously, leading them to behave prosocially toward others by being willing to help, by donating money to a good cause, or by punishing others for their unethical actions.

In Experiment 1, we tested whether having participants recall memories from their childhood would increase their sense of moral purity and the likelihood that they would help someone in the present. In Experiment 2, we tested whether recalling childhood memories would make people more likely to donate money to a good cause and whether this relationship would be mediated by an implicit measure of moral purity. In Experiment 3, we tested for moral purity as the mechanism explaining the relationship between childhood memories and prosocial behavior through moderation. In Experiment 4, we used a different form of prosocial behavior, 
namely punishment of others' ethically-questionable actions. Through this form of behavior, individuals punish others for their actions, even if the punishment is costly for them and yields no material gain (Fehr \& Gachter, 2002). In this study, we found that participants primed with childhood memories judged the ethically-questionable behavior of others more harshly compared to participants in a control condition. This study also tested whether having children moderates the relationship between childhood memories and prosocial behavior. Finally, in Experiment 5 we distinguished between recalling good versus bad memories from childhood, and demonstrated that the link between childhood memories and prosocial behavior holds for both types of memories.

\section{Experiment 1: Helping Others}

We designed Experiment 1 to provide initial evidence that recalling memories from childhood causes people to feel morally pure and behave prosocially toward others. First, we wanted to determine whether a sense of moral purity can be experienced when recalling and writing about one's own childhood. Second, we wanted to determine whether experiencing moral purity motivates people to help others in need.

To achieve these goals, we asked participants to recall positively-valenced memories from their childhood versus their last visit to the grocery store (in the control condition), and then we asked them to respond to items measuring moral purity. Toward the end of the study, participants were asked whether they wanted to help the experimenter with an additional, optional task, allowing us to assess prosocial behavior. We predicted that participants' recollection of their childhood would make them feel morally pure, leading them to be more helpful toward the experimenter.

\section{Method}


Participants. One hundred thirteen undergraduates (58 female; $M_{a g e}=20.53 ; S D=2.07$ ) from a university in the Southeastern United States participated in a laboratory study in exchange for partial course credit.

Procedure. Participants were directed to a computer in a laboratory room and began reading the instructions on the screen. In the first part of the study, participants were asked to describe events in their lives. They were told that they would write a brief essay on something that they do frequently, and then they would write a brief essay on something that happened at a particular time. They were told that they could spend 5-10 min writing each essay. The first essay asked them to describe their morning routine in detail; this was used to disguise the true purpose of the study. The second essay's topic varied by condition. In the childhood condition, participants wrote an essay in response to the following prompt: "Please think about your childhood and good memories you have from it. Please write a few paragraphs describing them and one event that you still remember to this date. Please provide as many details as possible so that another person reading what you wrote could understand how you felt at that time." In the control condition, the first part of the prompt read: "Please think about the last time you were at the supermarket shopping. Please write a few paragraphs describing this situation and one item or product that you purchased." The second part of the prompt was the same as in the childhood condition. Thus, participants in both conditions were instructed to describe something positive that happened in their lives, but we expected the control essays to have nothing to do with one's own childhood.

Participants then reported on a 7-point scale the extent to which, at the present moment, they felt the 10 positive emotions (i.e., attentive, interested, alert, enthusiastic, excited, inspired, proud, determined, strong and active, $\alpha=.93$ ) and the 10 negative emotions (distressed, upset, 
hostile, irritable, scared, afraid, ashamed, guilty, nervous, and jittery, $\alpha=.92$ ) that comprise the Positive and Negative Affect Schedule (PANAS; see Watson, Clark, \& Tellegen, 1988). After completing unrelated filler tasks for about 5 minutes, participants indicated their agreement on a 7-point scale (1=Strongly disagree, 7=Strongly agree) with two moral purity items and five personality-related filler items (e.g., "I have a good memory") presented in random order. The moral purity items were "I feel innocent," and "I feel morally pure." We used the mean of the two moral purity items as to measure moral purity $(\alpha=.84)$.

Finally, participants completed a 2-item manipulation check ("The writing task I completed made me think about the time I was a child," "The writing task I completed made me go back to my childhood") using a similar 7-point scale (1=Strongly disagree, 7=Strongly agree). We combined responses to the two items $(\alpha=.97)$ to form a single index.

The helping request was the last measure administered. Instructions on the computer screen informed participants that they had completed the study but that they had the option of helping the experimenter with an extra task described as "pilot testing for another project." The instructions clarified that this was totally voluntary and not part of the original experiment. On the next screen, participants indicated whether they wanted to help with this extra task. If they agreed to help, they went on to answer a brief questionnaire about sports and health habits. If they decided not to help, this questionnaire was skipped. Then participants were asked to guess the hypothesis of the study and to report whether they were suspicious of anything. Finally, they were debriefed.

\section{Results}

Preliminary analyses. An examination of the free-response essays showed that participants in the childhood-memories condition wrote about a wide variety of situations, such 
as listening to a particular type of music, playing with friends, or engaging for the first time in an activity such as riding a bicycle.

Three participants expressed suspicion that the request for help with the extra task was what the researchers were actually interested in. We excluded these three participants from all subsequent analyses for clarity of interpretation, but the results reported below were the same regardless of whether we included $(N=113)$ or excluded $(N=110)$ these suspicious participants.

Manipulation check. Our manipulation was effective: participants who recalled memories from their childhood reported the writing task made them think more about the time they were children $(M=5.43, S D=1.37)$ compared to participants in the control condition $(M=2.03, S D=1.49), t(108)=12.12, p<.001, d=2.36$.

Moral purity. As we predicted, participants in the childhood condition reported a higher mean moral-purity score $(M=3.73, S D=1.79)$ than did control participants $(M=2.38, S D=1.41)$, $t(108)=4.42, p<.001, d=0.86$.

Prosocial behavior. A larger percentage of participants who recalled childhood memories ( $75 \%$ of them) were willing to help the experimenter by completing the extra task than that of participants in the control condition $\left(54.5 \%\right.$ of them), $\chi^{2}(1, N=110)=4.72, p=.03$, Cramer's $\mathrm{V}=.21$. This result indicates that based on the odds ratio participants were 2.35 times more likely to help if they recalled childhood memories than if they recalled a neutral event.

Mediation by moral purity. When both condition and moral purity were entered into a logistic regression model predicting helping on the extra task, as hypothesized, moral purity was significant $(b=.94, S E b=.22)$, Wald $\chi^{2}=17.78, p<.001$, but condition was no longer significant ( $b=-.10, S E b=.50$ ), Wald $\chi^{2}<1, p=.85$. Using the bootstrapping method (with 10,000 iterations) recommended by Preacher and Hayes (2004), we tested the significance of the indirect effect of 
condition on helping behavior through self-reported moral purity. The $95 \%$ confidence interval for the indirect effect did not include zero $(.58,2.54)$, indicating that moral purity was a mediator in this experiment as we predicted.

Positive and negative affect. We then examined whether our manipulation influenced participants' positive and negative affect. Participants in the childhood-memories condition reported about the same levels of positive affect $(M=3.01, S D=1.22)$ as those in the control condition $(M=3.00, S D=1.35), t(108)<1, p=.96, d=.01$. Thus, affect was not positively correlated with recalling memories from one's own childhood. Similarly, negative affect was not correlated with recalling childhood memories $(M=1.63, S D=0.90$ vs. $M=1.47, S D=0.74, t[108]=1.06, p=.29$, $d=.21$ ), thus ruling out the possibility that the control condition was tedious compared to the childhood condition.

\section{Discussion}

After recalling and writing about memories from their childhood, participants were more likely to agree to help the experimenter. Furthermore, we demonstrated that recalling childhood memories led participants to experience a heightened sense of moral purity. Our first test of the mediation model (that remembering memories from one's own childhood leads to prosocial behavior because of an increased sense of moral purity) yielded a significant result, providing initial support for the mediating role of moral purity.

\section{Experiment 2: Donating Money to a Good Cause}

In Experiment 2, we provide further evidence for the relationship between childhood memories and prosocial behavior by using a different measure to assess prosocial behavior. Specifically, we employed a continuous measure by asking participants to donate money to a good cause, rather than relying on a single dichotomous measure as we did in Experiment 1. 
Experiment 2 differed from Experiment 1 in three other important ways. First, we used a different control condition. To provide a more controlled test of our hypotheses, participants in the control condition were asked to recall and write about memories from the time they were in high school (i.e., a different type of autobiographical memory). Second, we employed an implicit measure of moral purity in addition to a self-reported measure. Specifically, we used a wordcompletion task to measure non-conscious activation of the construct of moral purity. Wordfragment completion tests assess implicit cognitive processes (Bassili \& Smith, 1986; Tulving, Schacter, \& Stark, 1982), thus allowing us to test whether childhood memories influence participants' choice of words and their implicit thought processes.

Finally, we included a measure of nostalgia in Experiment 2 to test this emotion as alternative potential mediator of our effect. Childhood memories are one of the many memories from one's own past that can promote nostalgic feelings (Sedikides, Wildschut, Arndt, \& Routledge, 2008). In turn, nostalgic feelings may lead to prosocial behavior because of three main reasons. First, nostalgia serves as a repository of positive affect (Wildschut, Sedikides, Arndt, \& Routledge, 2006) and leads people to experience "a feeling of elation" (Kaplan, 1987, p. 465). And previous research has found that positive affect often promotes prosocial behaviors (e.g., Berkowitz, 1987; Carlson, Charlin, \& Miller, 1988; Eisenberg \& Fabes, 1991). Second, nostalgia enhances positive self-regard (Wildschut et al., 2006), it increases the implicit accessibility of positive self-attributes and attenuates self-esteem defense (Vess, Arndt, Routledge, Sedikides, \& Wildschut, 2008). In turn, this positive self-regard may lead to otheroriented behaviors that can reinforce one's own positive self-image as demonstrated by work on moral identity (Aquino \& Reed, 2002). Finally, nostalgia strengthens social bonds (Wildschut et al., 2006). During nostalgic reverie, "the mind is "peopled"” (Hertz, 1990, p. 195). When 
individuals experience nostalgic feelings, close others come to be momentarily part of one's present. This heightened sense of social connection may lead to an increased concern for others and, as a result, promote prosocial behavior. In fact, when people feel socially excluded, they are less likely to behave prosocially (Twenge et al., 2007).

\section{Method}

Participants. Eighty-seven undergraduates (44 female; $M_{a g e}=20.89 ; S D=1.85$ ) from local universities in the Southeastern United States participated in a laboratory study in exchange for $\$ 12$ (\$2 show-up fee and an additional \$10).

Procedure. Participants were seated at a computer in a laboratory room and were informed that they would participate in a series of unrelated tasks. They first received a 15-min bogus task after which they received $\$ 5$. Then, they were given the essay-writing instructions used in Experiment 1 but this time we used a different prompt for the control condition. We asked participants to "Please think about your life as a student in high school and good memories you have from it. Please write a few paragraphs describing them and one event that you still remember to this date. Please provide as many details as possible so that another person reading what you wrote could understand how you felt at that time." Participants received $\$ 5$ for this second task, which included writing essays and answering a series of short questionnaires.

After writing their essays about memories from their childhood or memories from their time in high school, participants completed a 2-item measure of nostalgia (from Zhou, Sedikides, Wildschut, \& Gao, 2008): "Right now, I am feeling quite nostalgic" and "Right now, I am having nostalgic feelings" $(\alpha=.88)$ using a 7-point scale ( $1=$ Strongly disagree, $7=$ Strongly agree).

Next, they completed the word-completion task. In this task, participants received a list of words with letters missing and were asked to fill in the blanks to make complete, meaningful 
words using the first word that came to mind. Of the six word fragments, three $\left(\mathrm{P}_{-} \mathrm{R}_{-}, \mathrm{M}_{-} \mathrm{R}_{-}\right.$ _, and $\mathrm{V}_{-} \mathrm{R} \mathrm{T}_{-_{-}}$) could be completed as words related to moral purity (pure, moral, and virtue) or as unrelated words (e.g., part, mural, and vortex).

Participants then completed the 20 -item version of the PANAS ( $\alpha=.70$ for positive affect and $\alpha=.90$ for negative affect, Watson et al., 1988), and rated their agreement with the two moral purity items and the five personality-related filler items used in Experiment 1. Participants were asked to respond to these statements on the basis of how they were feeling at that moment in an attempt to measure state moral purity. The mean of the two moral purity items was used as the measure of moral purity $(\alpha=.80)$.

Finally, participants were informed they had completed the study. The final instructions informed them they could donate money for the victim of the Japan earthquake (the earthquake happened about a month before the experiment took place):

Our research team is interested in collecting donations for the victims of the Japan earthquake. Please indicate if you are willing to make a donation. If so, we'll ask you to leave money in the envelope next to the computer. If you do not have money with you but intend to donate please write the amount you intend to donate below (next question) with your name. You can bring the money to the lab any day of the week this week.

All the participants who indicated they wanted to donate money made their donation at the time of the session. (We note that the amount participants specified in the question regarding their willingness to donate matched the amount participants actually donated by leaving money in the envelope.)

Finally, participants completed a final questionnaire where they reported demographic information, answered the two-item manipulation check $(\alpha=.77)$, were asked to guess the study hypotheses, and were debriefed.

\section{Results}


Preliminary analyses. No participant guessed any of the study hypotheses, and no participants reported suspicion in this study. Therefore, we did not exclude any participants from our analyses.

Manipulation check. Participants who wrote an essay about their childhood reported the task made them think about their childhood significantly more $(M=4.68, S D=0.99)$ than did those who wrote about their time in high school $(M=2.74, S D=0.86), t(85)=9.74, p<.001, d=.2 .09$.

Moral purity. Participants in the childhood-memories condition reported greater moral purity $(M=3.28, S D=1.16)$ than did participants in the control condition $(M=2.13, S D=1.09)$, $t(85)=4.79, p<.001, d=1.03$. This result was mirrored by the implicit measure of moral purity we included in the experiment. Participants in the childhood-memories condition used significantly more words related to moral purity in the word-completion task $(M=1.41, S D=0.82)$ than did participants in the control condition $(M=0.81, S D=0.88), t(85)=3.27, p=.002, d=0.70$. In fact, the explicit and implicit measures of moral purity were significantly and positively correlated with one another $(r=.52, p<.001)$.

Amount donated. Consistent with the increase in helping observed in Experiment 1, participants who wrote about childhood memories donated more money to the victims of the Japan earthquake $(M=\$ 2.02, S D=1.83)$ than did participants in the control condition $(M=\$ 1.23$, $S D=1.79), t(85)=2.04, p=.045, d=0.44$. A larger percentage of participants in the rememberingchildhood condition $(63.6 \%, 28$ out of 44$)$ donated money compared to that in the control condition $(41.9 \%, 18$ out of 43$), \chi^{2}(1, N=87)=4.14, p=.042$, Cramer's V=0.22. Based on the odds ratio, participants were 2.43 times more likely to donate if they recalled childhood memories than if they recalled memories from high school. Together, these results indicate that childhood memories promoted prosocial behavior. 
Mediation by moral purity. When both condition and moral purity were entered into a regression predicting donated amount of money (our measure of prosocial behavior), condition was no longer significant ( $b=-.15, S E b=.38 ; t=-0.40, p=.69$ ), whereas moral purity significantly predicted prosocial behavior $(b=0.81, S E b=.15 ; t=5.38, p<.001)$. The Preacher and Hayes (2004) bootstrapping technique (with 10,000 iterations) produced a $95 \%$ confidence interval for the indirect effect that excluded zero $([0.50,1.58])$. Thus, moral purity significantly mediated the relationship between childhood memories and prosocial behavior. Note that we obtained support for mediation also when considering the likelihood to donate rather than the amount donated as the dependent variable, and also when considering the implicit measure of moral purity as the mediator in analyses with either dependent variable.

Nostalgia and affect. Nostalgia, and the mean of the positive affect words from the PANAS were not mediators for the effect. Although participants who recalled and wrote about memories from their childhood did report being more nostalgic after writing the essay $(M=3.98$, $S D=1.14)$ than did participants in the control condition $(M=2.45, S D=1.36), t(85)=5.55, p<.001$, $d=1.19$, the effect of nostalgia was not significant in a mediation model predicting the amount of money donated from condition and nostalgia $(b=-.08, S E b=.16 ; t<1, p=.62)$. As for affect, we did not find significant differences in either positive affect or negative affect, both $t \mathrm{~s}(85)<1$.

\section{Discussion}

Consistent with Experiment 1, participants who recalled childhood memories donated more money to victims of the Japan earthquake than did participants in a control condition. Mirroring this result, a larger proportion of participants in the childhood-memories condition engaged in prosocial behavior by donating some money as compared to those in the control condition. Experiment 2 also provides further support for the hypothesis that moral purity 
mediates the relationship between childhood memories and prosocial behavior by using both an implicit and an explicit measure of moral purity. Recalling childhood memories caused people to feel morally pure, and as a result, they behaved prosocially.

These data also constitute evidence against a plausible alternative explanation for the effect of childhood memories. People who wrote about positively-valenced memories from their own childhood felt more nostalgic after describing the event than did people who wrote about an event in their more recent past (high-school). This is consistent with other research showing that people feel nostalgic after recalling an event from their past, especially when it is from a distant past (e.g., Sedikides et al., 2008; Wildschut et al., 2006). Nostalgic feelings did not mediate the relationship between recalling memories from one's own childhood and increased prosocial behavior. Similarly, positive affect did not differ depending on whether participants recalled childhood versus not. We instead found support for our hypothesis that moral purity is the mediator.

\section{Experiment 3: Manipulating Moral Purity}

Our first two experiments demonstrated that the relationship between childhood memories and prosocial behavior is mediated through moral purity, using both explicit and implicit measures. Experiment 3 explored this same process through moderation. In addition to manipulating the type of memories we asked participants to recall and write about (childhood memories vs. control), we introduced a manipulation of moral purity to test whether priming participants with the concept of moral purity would lead to greater prosocial behavior only for those in the control condition (who did not already feel morally pure after the recall task).

\section{Method}


Participants and design. One-hundred and one students and staff members (42 male; $\left.M_{\text {age }}=23.82 ; S D=7.92\right)$ from a university in the Southeastern United States participated in a 30minute laboratory study for $\$ 6$. Participants were randomly assigned to one of four conditions in a 2 (memories: childhood memories vs. control condition) X 2 (priming: neutral vs. moral purity) between-subjects design.

Procedure. Participants were informed that they would be completing a series of unrelated task. First, they completed the same writing task as in Experiment 2. We used this task to manipulate the type of memories participants recalled: childhood vs. high-school memories.

As their second task, participants completed a scrambling-sentence task that exposed them to moral-purity related words or neutral words (from Schnall, Benton, \& Harvey, 2008). Participants were told that, "This is a test of how people perceive word relationships according to their first immediate impression. It consists of sets of four words which are in a "scrambled" order. By selecting 3 words in a set, you can make a complete sentence.” Participants were given 40 sets of words and were told to choose any combination of three words they wished, as long as they made a complete sentence. They were randomly assigned to one of two conditions. In the neutral prime condition, all 40 sets of words formed neutral sentences. In the moral-purity prime condition, 20 of the sets included words related to the theme of purity and cleanliness (e.g., pure, washed, clean, immaculate, pristine), and the other 20 sets contained only neutral words. For example, participants in the moral purity condition were asked to construct a sentence out of the set of words: they felt clean I and immaculate fresh felt she.

Once participants completed the scrambling-sentence task, they proceeded to the next task which included two measures of moral purity (we counterbalanced the order in which we presented the two measures to participants): the implicit, word-fragment completion task used in 
Experiment 2, and a new measure of moral purity (which substituted the self-reported measure used in Experiments 1 and 2). For the new measure, we asked participants to indicate their preferences for five different products shown in pictures presented on the screen. One of the product choices was between two stuffed animals: a white lamb and a black bear (see Appendix for pictures). The other four choices were neutral. Given the demonstrated association between white and moral and black and immoral (Sherman \& Clore, 2009), we coded participants' preference for the white lamb as a preference for moral purity. ${ }^{2}$

At the end of the study, participants were presented with an opportunity to donate (a task adapted from Twenge et al., 2007: Experiment 1). Participants received \$6 (4 dollars in $\$ 1$ bills and 8 quarters) and were told that the money was theirs to do with as they wished. Participants were told that the money was in quarters because participants in other conditions had the money doled out to them over the course of the experiment. At the end of the study, the experimenter mentioned that she needed to grab the final questionnaire from another room and said, "Before I go, I want to mention that we're taking up a collection for the Student Emergency Fund. It's a good cause. If you'd like to donate, that would be great. If not, that's totally fine too." As she said this, she pointed to the box on the table, which had a slit in the top, a sign reading "Student Emergency Fund," and a description detailing the purpose of the fund: helping undergraduates with unanticipated expenses. The experimenter explained that if participants did not want to donate, they would have to put no money in the envelope for the donation located on their desk but had to still place the envelope in the donation box. (In this way we assured that participants were not influenced by the decisions of others.)

\footnotetext{
${ }^{2}$ We conducted a pilot study on a non-overlapping group of participants $(N=48)$ to confirm that the white lamb stuffed animal was rated as representing moral purity (as defined in this paper) more than the black bear.
} 
The experimenter then left the room for about two minutes before returning to ask participants to complete the final questionnaire, which included demographic questions, a twoitem manipulation check for the type of memories recalled $(\alpha=.84)$ and prompts for suspicion. Then, she debriefed participants. After participants left, the experimenter counted the money in the box. Participants left their donation in an envelope with a small-printed lab ID on it so that we could track the amount each participant donated (if any).

We expected the moral-purity prime to moderate the relationship between childhood memories and prosocial behavior such that this prime would promote virtuous behavior only in the control condition. In fact, in the childhood memories condition, we expected participants to already feel morally pure because of the recall task in which they wrote about memories from their childhood.

\section{Results}

Preliminary analyses. No participant guessed any of the study hypotheses, and no participants reported suspicion in the final questionnaire. Therefore, we did not exclude any participants from our analyses.

Manipulation check. A 2 (memory recalled) X 2 (prime) ANOVA revealed only a significant effect for our childhood-memories manipulation, $F(1,97)=64.58, p<.001, \eta_{p}{ }^{2}=.40$ : Participants who recalled and wrote about their childhood reported the task made them think about their childhood significantly more $(M=4.38, S D=1.00)$ than did those who wrote about their time in high school $(M=2.61, S D=1.19)$.

Moral purity. A similar analysis using our implicit measure of moral purity revealed a significant interaction between our two manipulations, $F(1,97)=4.73, p=.032, \eta_{p}{ }^{2}=.047$. In the control condition, being exposed to the moral purity prime increased accessibility to the concept 
of moral purity $\left(M_{\text {purity_prime }}=1.21, S D=1.22\right.$ vs. $\left.M_{\text {neutral_prime }}=0.38, S D=0.71\right), F(1,97)=8.06$, $p=.006$. Instead, in the childhood-memories condition, we found no differences in the number of moral words recalled based on the type of prime participants had received $\left(M_{\text {purity_prime }}=1.26\right.$, $S D=1.10$ vs. $\left.M_{\text {neutral_prime }}=1.31, S D=0.97\right), F(1,97)<1, p=.89$.

We found similar results when considering the choice for the stuffed animal signaling a preference for purity (i.e., the white lamb), $B=-2.06(\mathrm{SE}=.89)$, Wald=5.36, $p=.021$. In the control condition, being exposed to the moral purity prime increased participants' likelihood to choose the white lamb $(62.5 \%$ vs. $16.7 \%), \chi^{2}(1, N=48)=10.54, p=.001$, Cramer's V=0.47. Instead, in the childhood-memories condition, we found no differences in the percentage of participants who chose the white lamb based on the type of prime (59.3\% vs. $57.7 \%), \chi^{2}(1, N=53)<1, p=.91$, Cramer's V=0.02.

We note that these two measures assessing moral purity were positively and significantly correlated $(r=.38, p<.001)$.

Amount donated. We conducted a similar analysis using the amount donated as the dependent variable. As predicted, the interaction between our two manipulation was significant, $F(1,97)=4.52, p=.036, \eta_{p}{ }^{2}=.045$. In the control condition, the moral purity prime increased the amount participants donated $\left(M_{\text {purity } \_ \text {prime }}=\$ 0.91, S D=1.01\right.$ vs. $\left.M_{\text {neutral_prime }}=\$ 0.20, S D=0.44\right)$, $F(1,97)=7.56, p=.007$. Instead, in the childhood-memories condition, we found no differences in the amount participants donated based on whether they had been exposed to a moral purity or a neutral prime $\left(M_{\text {purity_prime }}=\$ 0.92, S D=1.01\right.$ vs. $\left.M_{\text {neutral_prime }}=\$ 0.96, S D=0.96\right), F(1,97)<1, p=.87 .^{3}$

\footnotetext{
${ }^{3}$ We also note that participants who wrote about childhood memories donated more money $(M=\$ 0.94, S D=0.98)$ than did participants in the control condition $(M=\$ 0.55, S D=0.85), F(1,97)=3.80, p=.031, \eta_{p}{ }^{2}=.05$. The effect of our prime manipulation was only marginally significant $\left(F[1,97]=3.45, p=.07, \eta_{p}{ }^{2}=.034\right)$ such that the moral purity prime increased the amount donated $\left(M_{\text {purity_prime }}=\$ 0.91, S D=1.00\right.$ vs. $\left.M_{\text {neutral_prime }}=\$ 0.60, S D=0.84\right)$.
} 
We found the same results when considering the percentage of participants who decided to donate, which is depicted in Figure 1.

Moderated mediation. Next, we examined whether our implicit measure of moral purity would explain the moderating effect of the prime on the relationship between childhood memories and the amount participants donated, using a moderated path analysis (Edwards \& Lambert, 2007). We expected that the prime would moderate the effect of childhood memories on moral purity, which would directly predict greater prosocial behavior. Regression analyses showed that when moral purity was entered into the equation, the interaction between our two manipulations became non-significant, whereas moral purity significantly predicted larger donations (Table 1). We computed simple effects for our childhood memories manipulation at two levels of the prime (moral purity prime vs. neutral prime) using bias-corrected confidence intervals, drawing 1000 random samples with replacement from the full sample. As shown in Table 2, we found support for moderated mediation: the prime participants had been exposed to moderated the indirect effect of childhood memories on the amount donated through our implicit measure of moral purity. Importantly, we find results in support of moderated mediation also when considering the preference for the white lamb as our measure of moral purity.

\section{Discussion}

The results of Experiment 3 provide further support for our hypotheses by showing that childhood memories promote prosocial behavior through heightened moral purity. Importantly, in Experiment 3 we provided evidence for the process explaining the link between childhood memories and prosocial behavior using moderation: only in the control condition we found that participants increased the amount they donated when they were primed with moral purity.

\section{Experiment 4: Judging and Punishing the Actions of Others}


So far, we have demonstrated that remembering childhood promotes prosocial behavior through heightened moral purity. In Experiment 4, we focus on a different type of prosocial behavior: punishment of the actions of others. We expected that childhood memories would lead people to judge the behavior of others more critically and to punish it more harshly.

The design of Experiment 4 differed from our previous studies in another critical way. To increase the generalizability of our findings, instead of relying on university students, we used a different sample that included people who had children of their own. Having children may weaken the type of associations people make when remembering their own childhood. First, the daily grind of living with a child may desensitize a person. Alternatively, constantly taking care of a child may exhaust prosocial tendencies toward non-family members. It is also possible that parents may see their children as somewhat selfish. Because of these reasons, the association between childhood and moral purity may be strong only for individuals who do not have children of their own (very likely the students in Experiments 1-3).

\section{Method}

Participants. One hundred twenty adults ( 72 female; $M_{a g e}=44.12 ; S D=14.87$; age range: 18-65) from a US representative online pool (recruited through Qualtrics) participated in the study in exchange for $\$ 4$. Forty-one percent of the participants reported having children.

Procedure. Participants were informed the study included several unrelated task. As their first task, they engaged in the writing task used in Experiments 2 and 3 for about 10 minutes. We used the writing task to introduce our manipulation of remembering childhood. Next, participants completed the implicit measure of moral purity (i.e., the word-fragment completion task) as well as the second measure of moral purity used in Experiment 3 (i.e., choosing between two stuffed animals). We counterbalanced the order of presentation of these two measures. 
As their next task, participants completed a short version of the PANAS (positive affect, $\alpha=.91$; negative affect, $\alpha=.94)$ and questions assessing nostalgia $(\alpha=.98)$ as in Experiment 2 . After completing unrelated filler tasks for about 2 minutes, participants were presented with a scenario describing the behavior of another person, Steve. They were asked to read it carefully and then answer a few questions about it. The scenario read,

Imagine that Steve has an important interview tomorrow, which will determine whether or not he will be able to get a really good job as an analyst. He is suitable for the job but he is worried about the interview being demanding. Steve is the type of person who does not perform at his best under stress. The questions for the interview will be chosen at random from a list that is kept in an online document which is password protected. Steve is the last person to leave the room after an introductory luncheon for all the job candidates. As he is about to leave, he notices that a company representative has left on the table a folder with information about tomorrow's interview. He has the opportunity to write down the password and use it to prepare for the interview. Nobody would ever learn about this. Steve decides to open the folder and copy the password on his notebook before leaving.

Participants were asked to indicate the extent to which they thought Steve's behavior was unethical, wrong, and morally inappropriate $(\alpha=.85)$ using a 7 -point scale $(1=$ Not at all, $7=$ Very much). They were then asked to imagine the person conducting the interview found out about Steve's actions, and then indicate how harshly they would punish the behavior if they were in the interviewer's shoes, even if punishing Steve's behavior meant potentially creating extra costs for the company by rescheduling the interviews (1=Not at all, 7=Very harshly).

Finally, participants answered the same 2-item manipulation check used in our previous experiments $(\alpha=.85)$, followed by a few demographic questions.

\section{Results}

Manipulation check. Participants who recalled memories from their childhood reported the writing task made them think about the time they were children $(M=4.92, S D=1.52)$ more 
than participants in the control condition $(M=3.71, S D=1.74), t(118)=4.07, p<.001, d=0.74$, suggesting that, once again, our manipulation was effective.

Ethical judgment and punishment. Remembering events from their childhood affected participants' judgments of Steve's behavior. Participants reported Steve's behavior to be more unethical in the remembering-childhood condition $(M=6.07, S D=1.08)$ than in the control condition $(M=5.57, S D=0.87), t(118)=2.79, p=.006, d=0.51$. They also indicated they would punish Steve's behavior more harshly if they were in the interviewer's shoes $(M=5.49, S D=1.42$ vs. $M=5.00, S D=1.20), t(118)=2.04, p=.043, d=0.37$.

Moral purity. Participants in the remembering-childhood condition completed the wordfragment task with more purity-related words $(M=1.26, S D=0.79)$ than did control participants $(M=0.66, S D=0.76), t(118)=4.24, p<.001, d=0.78$. In addition, they were more likely to choose the white lamb stuffed animal as their preferred choice in the product choice task, $(55.7 \%$ vs. $28.8 \%), \chi^{2}(1, N=120)=8.90, p=.003$, Cramer's $\mathrm{V}=0.27$. The two measures of moral purity were positively and significantly correlated $(r=.24, p=.009)$.

Having children as moderator. We examined whether having children moderated the relationship between childhood memories and moral purity, and the relationship between childhood memories and ethical judgments. Regression analyses revealed no significant interaction between our manipulation of childhood memories and having children in predicting either outcome (both $p s>15$ ). We found similar results when using "having children below the age of 6" as the moderating variable. (We also note that the nature and significance of our results did not change when using "having children" as a control variable in our analyses.) These results do not support the hypothesis that having children moderates the effects demonstrated so far. 
Mediation by moral purity. When both condition and our implicit measure of moral purity were entered into a regression predicting ethical judgment, condition was no longer significant ( $b=.26, S E b=.18 ; t=1.41, p=.16)$, whereas moral purity significantly predicted ethical judgment ( $b=.40, S E b=.11 ; t=3.63, p<.001)$. The Preacher and Hayes (2004) bootstrapping technique (with 10,000 iterations) produced a 95\% confidence interval for the indirect effect that excluded zero (.09 to .46), thus suggesting a significant indirect effect. We note that we find the same results in support for mediation when considering the choice of the white lamb as the mediator.

Nostalgia and affect. The mean of both positive and negative affect words from the short-form PANAS did not differ between conditions (both $p \mathrm{~s}>.63$ ). As for nostalgia, it was about the same in both the childhood-memories condition $(M=3.96, S D=1.64)$ and in the control condition $(M=3.63, S D=1.84), t(118)=1.05, p=.30, d=0.19$.

\section{Discussion}

In Experiment 4, recalling childhood memories led participants to be more critical of others' ethically-questionable behaviors and punish them more harshly, compared to a control condition. Furthermore, providing additional support for our predictions, we found that being reminded of memories from childhood led participants to experience a heightened sense of moral purity, and these feelings mediated the relationship between childhood memories and ethical judgments. Importantly, these effects were not moderated by having children: both parents and people without children experienced heightened moral purity when recalling memories from their childhood, and they both judged others' ethically-questionable behavior equally harshly.

\section{Experiment 5: Good and Bad Childhood Memories}


In Experiments 1-4, participants who recalled memories from their childhood reported higher moral purity and engaged in more prosocial behavior than control participants. Our last study included a condition in which participants are asked to recall and write about negativelyvalenced memories from their childhood to test whether valence moderates the relationship between childhood memories and prosocial behavior.

\section{Method}

Participants. One hundred nine students and staff members ( 47 female; $M_{a g e}=23.58$; $S D=4.48$ ) from local universities in the Southeastern United States participated in a laboratory study in exchange for $\$ 6$. Participants were randomly assigned to one of three conditions: goodchildhood memories, bad-childhood memories, or control condition.

Procedure. Participants were informed that the study included several unrelated tasks. We used the same procedure as in Experiment 1, but with three important differences. First, we introduced a third condition. In the control condition and in the good-childhood memories condition, we used the same instructions for the writing task used in Experiments 2-4. In the badmemories condition, instead, we asked participants to "think about your childhood and bad memories you have from it. Please write a few paragraphs describing them and one event that you still remember to this date." Second, differently from Experiment 1, we included an implicit measure of moral purity (i.e., the word-completion task) rather than an explicit, self-reported measure. Third, at the end of study, participants answered not only the same 2-item manipulation check used in our previous studies $(\alpha=.88)$, but they also indicated the extent to which they wrote about a positive experience ( $1=$ not at all, $7=$ extremely). As in Experiment 1 , our dependent variable was the likelihood of participants to help the experimenter with a supplementary task.

\section{Results}


Preliminary analyses. Three participants were excluded from the analyses because they reported being suspicious of the request for help. No participant guessed any of the relationships being tested in the research.

Manipulation check. Participants who recalled good memories from their childhood $(M=5.36, S D=1.11)$ and those who recalled bad childhood memories $(M=5.53, S D=1.13)$ both reported the writing task made them think more about the time they were children compared to control participants $(M=2.77, S D=1.34 ; p<.001$ for both comparisons $), F(2,103)=59.61, p<.001$, $\eta_{p}{ }^{2}=.54$. Participants' answer on this manipulation check was no different between the two childhood-memories conditions $(p=.55)$. These results suggest that, once again, our manipulation was effective.

Participants also indicated the extent to which they wrote about a positive experience. Their rating on this question varied by condition, $F(2,103)=48.84, p<.001, \eta_{p}{ }^{2}=.49$ : it was higher in the good-childhood-memories condition $(M=6.03, S D=1.36)$, followed by the control condition $(M=4.36, S D=1.81)$, and it was the lowest in the bad-childhood-memories condition $(M=2.17, S D=1.71 ; p<.001$ across all comparisons $)$.

Helping. Participants' likelihood to help also varied by condition in the same direction, $\chi^{2}(1, N=106)=6.97, p=.031$, Cramer's V=0.26. Participants were more likely to help in the goodchildhood-memories condition $(57.1 \%, 20 / 35)$ and in the bad-childhood-memories condition $(51.4 \%, 18 / 35)$ than in the control condition $(27.8 \%, 10 / 36 ; p<.05$ for both comparisons). Helping did not significantly vary depending on the valence of the childhood memories that participants recalled $(p=.63)$.

Accessibility to moral-purity related concepts. Participants in the good-childhoodmemories condition and those in the bad-childhood-memories condition used significantly more 
words related to moral purity in the word-completion task $(M=1.34, S D=0.87$ and $M=1.43$, $S D=0.95$, respectively) than did participants in the control condition $(M=0.89, S D=0.92 ; p<.05$ for both comparisons), $F(2,103)=3.59, p=.031, \eta_{p}{ }^{2}=.07$. Accessibility to moral purity concepts did not differ between the two childhood memories conditions $(p=.70)$.

Mediation by moral-purity. When we entered both childhood memories ( 1 for both good and bad childhood memories, and 0 for the control condition) and our measure of moral purity into a logistic regression model predicting helping, moral purity was significant $(b=.95$, $S E b=.26)$, Wald $\chi^{2}=13.47, p<.001$, but condition was no longer significant $(b=.82, S E b=.48)$, Wald $\chi^{2}=2.91, p=.09$. The Preacher and Hayes (2004) bootstrapping technique (with 10,000 iterations) produced a $95 \%$ confidence interval for the indirect effect that excluded zero (.10 to 1.08). Thus, our implicit measure moral purity significantly mediated the relationship between childhood memories and helping.

Positive and negative affect. On average, positive affect $(\alpha=.94)$ was higher in the goodchildhood-memories condition $(M=4.83, S D=1.38)$ compared to both the bad-childhoodmemories condition $(M=3.95, S D=1.58)$ and the control condition $(M=3.76, S D=1.50 ; p<.02$ for both comparisons), $F(2,103)=5.13, p=.007, \eta_{p}{ }^{2}=.09$. As for the mean score of negative affect $(\alpha=.96)$, it was higher in the bad-childhood-memories condition $(M=2.80, S D=1.50)$ compared to both the good-childhood-memories condition $(M=1.76, S D=1.52)$ and the control condition $(M=1.43, S D=0.78 ; p<.01$ for both comparisons $), F(2,103)=10.66, p<.001, \eta_{p}{ }^{2}=.17$. Yet, these emotions were not significant in a mediation model predicting helping from condition and affect (positive affect: $b=.04, S E b=.13$, Wald $\chi^{2}<1$; negative affect: $b=-.04$, SE $b=.15$; Wald $\chi^{2}<1$ ).

\section{Discussion}


In Experiment 5, recalling childhood memories, compared to a control condition, led participants to experience a heightened sense of moral purity, and to greater helping. In addition, the results of this study show that the valence of the childhood memories participants recalled did not moderate the link between childhood memories and prosocial behavior: both positivelyvalenced and negatively-valenced childhood memories led to a heightened sense of moral purity, and promoted participants' likelihood to help.

\section{General Discussion}

In five experiments, we found that people experience a heightened sense of moral purity and are thus more likely to behave prosocially after recalling memories from their own childhood than neutral events or memories from their more recent past (i.e., time in high school).

In Experiment 1, participants instructed to recall childhood memories were more likely to help the experimenter with a supplementary task than were participants in a control condition. This effect was mediated by self-reported moral purity. In Experiment 2, childhood memories increased the amount of money participants donated to a good cause compared to memories from one's experience in high school, and this effect was mediated by both an implicit and an explicit measure of moral purity. Experiment 2 also showed that nostalgia or other positive affect after recalling and writing about one's own childhood did not mediate the effect. In Experiment 3, we provided evidence for moral purity as mediator explaining the relationship between childhood memories and prosocial behavior through moderation. In Experiment 4, childhood memories led participants to judge the ethically-questionable behavior of others more critically and punish it more harshly. Finally, in Experiment 5, participants who recalled childhood memories were more likely to help. This study also demonstrated that the valence of childhood memories does not moderate the link between recalling one's own childhood and prosocial behavior. 
Taken together, these experiments support a model in which remembering childhood leads to heightened moral purity, which, in turn, promotes prosocial behavior. We found that one's perceived moral purity as well as the activation of morality-related constructs in one's mind can change from moment to moment_-increasing when individuals remember their own childhood - and that they can encourage prosocial behavior, even in domains unrelated to the original event that made them feel morally pure. We also captured the effect using a range of outcomes, such as helping an experimenter, donating money to a good cause, and punishing the actions of others more harshly.

Together, these results make several contributions to the extant literature. First, extending prior work on autobiographical memory, we proposed and found that childhood memories activate the concept of moral purity that, in turn, promotes prosocial behavior. Prior research has stressed the important role autobiographical memory plays in forming our identity. Here, we demonstrated that by eliciting a sense of purity and innocence, childhood memories impact one's moral self-concept, with important consequences for behavior.

Second, we provide a definition for the construct of moral purity and establish the powerful consequences it has on individual ethical behavior. Although prior work in moral psychology has referred to moral purity (for instance when examining the consequences or antecedents of physical purity), it has provided no definition for this construct. We hope that by defining moral purity and demonstrating effective ways of measuring it we will inspire future work in this important area.

Third, these results contribute to existing research on the determinants of prosocial behavior. Several scholars have focused on the role of emotions such as sympathy (feeling concern for the other) and empathy (feeling as the other feels) in predicting increased prosocial 
behaviors and reduced antisocial behaviors (e.g., Batson, 1991, 1998; Eisenberg \& Miller, 1987; Miller \& Eisenberg, 1988). Here, we identified another important internal state that promotes prosocial behavior, namely the conscious and unconscious experience of moral purity triggered by childhood memories. While sympathy and empathy are feelings individuals experience in relations to other people, moral purity seems to be a more self-focused state, which can motivate other-oriented behaviors.

Our work also contributes to research on moral psychology and behavioral ethics. Over the last few decades, scholars have examined when and why even good people cross ethical boundaries, and have proposed that the more accurate explanations for immoral behavior may reside in underlying psychological processes (Ayal \& Gino, 2011; Messick \& Bazerman, 1996). Consistent with this view, studies have identified various psychological factors that consciously or unconsciously influence the decision to behave unethically (e.g., Chugh, Bazerman, \& Banaji, 2005; Mazar, Amir, \& Ariely, 2008; Gino, Ayal, \& Ariely, 2009; Monin \& Jordan, 2009). We extend this research by identifying a potentially effective solution to the pervasiveness of selfish motives and dishonesty in today's society: recalling childhood memories.

\section{Limitations and Future Research}

These contributions must be qualified in light of several important limitations of our research. First, our investigation focused on how childhood memories lead to the activation of concepts related to morality and heightened moral purity. Beyond moral purity, nostalgia, and affect, there may be additional mechanisms through which childhood memories promote prosocial behavior. Future research exploring other-oriented emotions and behaviors resulting from recalling one's own childhood could deepen our understanding of the relationships we investigated in this paper. For example, it will be worthwhile to examine whether childhood 
memories motivate prosocial behavior by increasing individuals' sense of psychological connectedness to others or their desire to be socially included, strengthening the motivation to behave prosocially towards others. In the future, researchers could examine the possibility that these factors influence moral purity and prosocial behavior.

Second, we used one particular manipulation for childhood memories: asking participants to recall and write about memories from their own childhood. We suggested that this type of autobiographical memory activates the concept of childhood. Future research could test the generalizability of our findings by using priming manipulations that activate the concept of childhood. For instance, research could test whether working in an office with colorful furniture, games and toys would lead to the same types of prosocial behaviors observed in our research.

Third, we did not investigate the role of possible moderators, other than the influence of the valence of childhood memories and having one's own children. Several important factors, both situational and trait-based, may moderate the relationships investigated in this paper. For instance, self-importance of moral identity may reduce the beneficial effects of remembering childhood on prosocial behavior. Moral identity is an important source of moral motivation, leading to greater concordance between one's moral principles and actions (Aquino \& Reed, 2002; Blasi, 1995). Since a stronger sense of moral identity is associated with performing more prosocial behaviors (e.g., Aquino \& Reed, 2002; Hardy, 2006), and less unethical behaviors (Aquino et al., 2009), the influence of childhood memories on prosocial behavior is likely to vary as a function of moral identity. People with a strong moral identity are more able to recognize their own moral objectives and social expectations by processing pre-existing moral conceptions and affective states before deciding upon a course of action (Bandura, 1991); thus, recalling 
childhood memories may produce stronger effects on behavior for people with a weak moral identity.

Future work could also examine the two moderators we considered in Experiments 4 and 5 in more detail, namely having children and recalling negative-valenced childhood memories. For instance, one could compare the behavior of first time parents to that of people without children. Or one could conduct a study on individuals who had particularly difficult childhood experiences. These would be more extreme conditions to test the moderating role of having children and recalling bad-childhood memories. Research using these samples could further our understanding of the consequences of childhood memories.

Finally, our research focused on the benefits of childhood memories with little attention to its potential costs (e.g., increased selfish or self-serving motives). Here, we suggested and demonstrated that people commonly associate childhood with innocence and moral purity. This evidence is consistent with developmental psychology research suggesting that children's ability to act deceptively requires cognitive mechanisms that are immature in young humans (e.g., Hala, Chandler \& Fritz, 1991), and with studies showing that children often behave prosocially (e.g., Hamlin et al., 2007; Jacob \& Dupoux, 2008; Warneken et al., 2007). Childhood memories may thus also activate a sense of naiveté, since they might lead us to remember how very naïve we were when we were children, and how we could not think two steps ahead (e.g., "if I give my ice cream to this stranger, I will not have any left for myself'). However, other empirical studies in developmental psychology suggest that young children are quite selfish, and that selfishness decreases as they become older (e.g., Lane \& Coon, 1972; Leventhal \& Anderson, 1970). This literature suggests that childhood memories may activate other constructs in individuals' mind, such as selfishness or egocentrism. Future research examining the conditions under which one 
type of construct (e.g., moral purity) is activated rather than others (e.g., selfishness) would deepen our understanding of the relationship between childhood memories, morality and prosocial behavior.

\section{Conclusions}

Our research has shown that people who recall childhood memories experienced a sense of moral purity (both consciously and unconsciously), and behaved more prosocially towards others as a result. By contributing to our general understanding of the determinants of prosocial behavior, this research points toward one possible solution to people's tendency to engage in self-serving and selfish acts. Future research in this vein thus has the potential to identify novel and simple methods to encourage prosocial behavior in people: By using tasks that can help individuals remember or relieve memories from their childhood, one can encourage helping and various forms of other-oriented behaviors. 


\section{Appendix}

Stimuli used to measure moral purity, Experiment 3

Instructions: If you were given the option to take a gift home with you, which of the following products would you rather choose to take home? Assume both stuffed animals are of the same size.
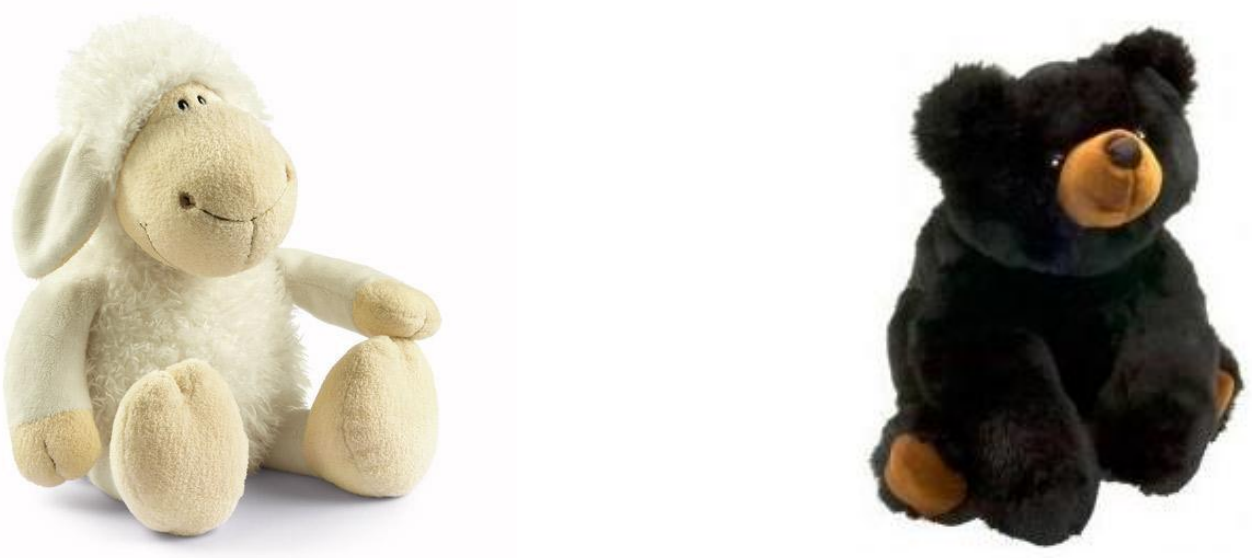


\section{References}

Aarts, H., \& Dijksterhuis, A. (2003). The silence of the library: Environmental control over social behavior. Journal of Personality and Social Psychology, 84, 18-28.

Anderson, J. R. (1976). Language, memory, and thought. Hillsdale, NJ: Erlbaum.

Anderson, J. R. (1983). The architecture of cognition. Cambridge, MA: Harvard University Press.

Aquino, K., \& Reed, A., II (2002). The self-importance of moral identity. Journal of Personality and Social Psychology, 83, 1423-1440.

Aquino, K., Freeman, D., Reed, A., II, Felps, W., \& Lim, V. (2009). Testing a social-cognitive model of moral behavior: The interactive influence of situations and moral identity centrality. Journal of Personality and Social Psychology, 97, 123-141.

Aries, P. (1962). Centuries of childhood. Suffolk, U.K.: The Chaucer Press.

Ayal, S., \& Gino, F. (2011). Honest rationales for dishonest behavior. In M. Mikulincer \& P. R. Shaver (Eds.), The Social Psychology of Morality: Exploring the Causes of Good and Evil. Washington, DC: American Psychological Association.

Baddeley, A. (1995). Working memory. In M. S. Gazzaniga (Ed.), The cognitive neuroscience (pp. 755-764). Cambridge, MA: MIT Press.

Bandura, A. (1989). Human agency in social cognitive theory. American Psychologist, 44, 11751184.

Bandura, A. (1991). Social cognitive theory of moral thought and action. In W. M. Kurtines \& J. L. Gewirtz (Eds.), Handbook of moral behavior and development (Vol. 1, pp. 45-103). Hillsdale, NJ: Erlbaum.

Barclay, C. R. \& DeCooke, P. A. (1988). Ordinary everyday memories: Some of the things of which selves are made. In U. Neisser and E. Winograd (Eds.), Remembering 
reconsidered: Ecological and traditional approaches to memory (pp. 91-125), Cambridge: Cambridge University Press

Bargh, J. A. (1994). The four horsemen of automaticity: Awareness, intention, efficiency, and control in social cognition. In R. S.Wyer, Jr., \&T. K. Srull (Eds.), Handbook of social cognition (2nd ed., pp. 1-40). Hillsdale, NJ: Erlbaum.

Bargh, J. A. (1997). Automaticity of everyday life. In R. S. Wyer, Jr. (Ed.), Advances in social cognition: Vol. 10. The automaticity of everyday life (pp. 1-61). Mahwah, NJ: Erlbaum.

Bargh, J. A., Chen, M., \& Burrows, L. (1996). Automaticity of social behavior: Direct effects of trait construct and stereotype activation on action. Journal of Personality and Social Psychology, 71(2), 230-244.

Bargh, J. A., Gollwitzer, P. M., Lee-Chai, A., Barndollar, K., \& Trotschel, R. (2001). The automated will: Nonconscious activation and pursuit of behavioral goals. Journal of Personality and Social Psychology, 81(6), 1014-1027.

Barlett, F. C. (1932). Remembering: A study in experimental and social psychology. Cambridge: Cambridge University Press.

Bassili, J. N., \& Smith, M. C. (1986). On the spontaneity of trait attribution: Converging evidence for the role of cognitive strategy. Journal of Personality and Social Psychology, $50,239-245$.

Batson, C. D. (1987). Prosocial motivation: Is it ever truly altruistic? In L. Berkowitz (Ed.), Advances in experimental social psychology (Vol. 20, pp. 65-122). New York: Academic Press.

Batson, C. D. (1991). The altruism question: Toward a social-psychological answer. Hillsdale, NJ: Erlbaum. 
Batson, C. D. (1998). Altruism and prosocial behavior. In D. T. Gilbert, S. T. Fiske, \& G. Lindzey (Eds.), The handbook of social psychology (Vol. 2, pp. 282-316). Boston: McGraw-Hill.

Bauer, P. J., Stennes, L., \& Haight, J. C. (2003). Representation of the inner self in autobiography: Women's and men's use of internal states language in personal narratives. Memory, 11, 27-42.

Berkowitz, L. (1987). Mood, self-awareness, and willingness to help. Journal of Personality and Social Psychology, 52(4), 721-729.

Blasi, A. (1995). Moral understanding and the moral personality: The process of moral integration. In W. M. Kurtines \& J. L. Gewirtz (Eds.), Moral development: An introduction (pp. 229-253). Needham Heights, MA: Allyn and Bacon.

Bloom, P. (in press). Moral psychology and moral progress. Nature.

Branscombe, N. A., Castle, K., Dorsey, A. G., Surbeck, E., \& Taylor, J. B. (2000). Early childhood education - A constructivist approach. Boston: Houghton Mifflin Company.

Brewer, W. F. (1986). What is autobiographical memory? In D. C. Rubin (Ed.), Autobiographical memory (pp. 25-49). Cambridge, England: Cambridge University Press.

Bruner, J. (1986). Actual minds, possible words. Cambridge, MA: Harvard University Press, Carlson, M., Charlin, V., \& Miller, N. (1988). Positive mood and helping behavior: A test of six hypotheses. Journal of Personality and Social Psychology, 55(2), 211-229.

Chugh, D., Bazerman, M. H., \& Banaji, M. R. (2005). Bounded ethicality as a psychological barrier to recognizing conflicts of interest. In D. A. Moore, D. M. Cain, G. F. 
Loewenstein, \& M. H. Bazerman (Eds.), Conflicts of interest: Problems and solutions from law, medicine and organizational settings. London: Cambridge University Press.

Cialdini, R. B. (2001). Influence: Science and practice (4 ${ }^{\text {th }}$ ed.). Boston: Allyn \& Bacon.

Cialdini, R.B., Schaller, M., Houlihan, D., Arps, K., Fultz, J., \& Beaman, A.L. (1987). Empathybased helping: Is it selflessly or selfishly motivated? Journal of Personality and Social Psychology, 52, 749-759.

Colegrove, F. W. (1899). Individual memories. American Journal of Psychology, 10, 228-255.

Collins, A. M., \& Loftus, E. E. (1975). A spreading-activation theory of semantic processing. Psychological Review, 82, 407-42.

Conway, M. A., \& Rubin, D. C. (1993). The structure of autobiographical memory. In A. E. Collins, S. E. Gathercole, M. A. Conway, \& P. E. M. Morris (Eds.), Theories of memory (pp. 103-137). Hove, Sussex, England: Erlbaum.

Conway, M. A. \& Pleydell-Pearce, C. W. (2000). The construction of autobiographical memories in the self-memory system. Psychological Review, 107, 261-288.

Conway, M. A. (1990a). Autobiographical memory: An introduction. Buckingham, England: Open University Press.

Conway, M. A. (1990b). Autobiographical memory and conceptual representation. Journal of Experimental Psychology: Learning, Memory, and Cognition, 16, 799-812.

Conway, M. A. (1996). Autobiographical memories. In E. Bjork \& R. Bjork (Eds.), Handbook of perception and cognition: Vol. W. Memory (pp. 165-194) Orlando, EL: Academic Press.

Dijksterhuis, A., \& Bargh, J. A. (2001). The perception-behavior expressway: Automatic effects of social perception on social behavior," in Advances in Experimental Social Psychology, Vol. 33, ed. M. P. Zanna, San Diego: Academic Press, 1-40. 
Dunn, J., \& Kendrick, C. (1979). Interaction between young siblings in the context of family relationships. In M. Lewis \& L.A. Rosenblum (Eds.), The child and its family (Genesis of Behavior, Vol. 2, pp. 143-168). New York: Plenum Press.

Edwards, J. R., \& Lambert, L. S. (2007). Methods for integrating moderation and mediation: A general analytical framework using moderated path analysis. Psychological Methods, 12, $1-22$.

Eisenberg, N., \& Fabes, R. A. (1991). Prosocial behavior and empathy: A multimethod developmental perspective. In M. S. Clark (Ed.), (1991). Prosocial behavior. (pp. 34-61). Thousand Oaks, US: Sage Publications, Inc.

Eisenberg, N., Fabes, R. A., \& Spinrad, T. L. (2006). Handbook of child psychology: Social, emotional, and personality development. Wiley, John and Sons, Incorporated New York.

Eisenberg, N., \& Miller, P. A. (1987). The relation of empathy to prosocial and related behaviors. Psychological Bulletin, 101, 91-119.

Fazio, R. H., Effrein, E. A., Falender, V. J. (1981). Self-perception following social interaction. Journal of Personality and Social Psychology, 41, 232-242.

Fehr, E., \& Gachter, S. (2002). Altruistic punishment in humans. Nature, 415, 137-140.

Festinger, L. (1957). A theory of cognitive dissonance. Stanford: Stanford University Press.

Fitzsimons, G. M., Chartrand, T. L., \& Fitzsimons, G. J. (2008). Automatic effects of brand exposure on motivated behavior: How "Apple" makes you think different. Journal of Consumer Research, 35, 21-35.

Fivush, R. (1993). Developmental perspectives on autobiographical recall. In G. S. Goodman \& B. L. Bottoms (Eds.). Child victims, child witnesses: Understanding and improving testimony (pp. 1-24). New York: Guilford. 
Fivush, R. (2011). The development of autobiographical memory. Annual Review of Psychology, $62,559-582$.

Foster, V., Mourato, S., Pearce, D., \& Ozdemiroglu, E. (2001). The price of virtue: The economic value of the charitable sector. Cheltenham, England: Elgar.

Frank, M. G., \& Gilovich, T. (1988). The dark side of self-and social perception: Black uniforms and aggression in professional sports. Journal of Personality and Social Psychology, $54(1), 74-85$.

Freeman, R. B. (1997). Working for nothing: the supply of volunteer labor. Journal of Labor Economics, 15(1), 140-166.

Frey, B. S., \& Meier, S. (2004). Social comparisons and prosocial behavior: Testing "conditional cooperation" in a field experiment. American Economic Review, 94(5), 1717-1722.

Galton, F. (1879). Psychometric experiments. Brain, 2, 149-162.

Gino, F., Ayal, S., \& Ariely, D. (2009). Contagion and differentiation in unethical behavior: The effect of one bad apple on the barrel. Psychological Science, 20, 393-398.

Greene, J. \& Haidt, J. (2002). How (and where) does moral judgment work? Trends in cognitive science, 6, 517-523.

Haidt, J. (2003). The moral emotions. In R. J. Davidson, K. Scherer, \& H. H. Goldsmith (Eds.), Handbook of affective sciences (pp. 852-870). Oxford: Oxford University Press.

Haidt, J., \& Graham, J. (2007). When morality opposes justice: Conservatives have moral intuitions that liberals may not recognize. Social Justice Research, 20, 98-116.

Haidt, J., \& Hersh, M. (2001). Sexual morality: The cultures and emotions of conservatives and liberals. Journal of Applied Social Psychology, 31, 191-221.

Haidt, J., \& Joseph, (2004). Intuitive ethics. Daedalus, 133, 55-66. 
Hala, S., Chandler, M., \& Fritz, A. S. (1991). Fledging theories of mind: Deception as a marker of three-year-olds' understanding of false belief. Child Development, 62, 83-97.

Hallie, P. (1979) Lest innocent blood be shed: the story of the village of Le Chambon and how goodness happened there. New York, Harper \& Row.

Hamlin, J. K., Wynn, K., \& Bloom, P. (2007). Social evaluation by preverbal infants. Nature, $450,557-560$.

Han, J. J., Leichtman, M. D., \& Wang, Q. (1998). Autobiographical memory in Korean, Chinese and American children. Developmental Psychology, 34(4), 701-713.

Hardy, S. A. (2006). Identity, reasoning, and emotion: An empirical comparison of three sources of moral motivation. Motivation and Emotion, 30, 207-215.

Heider, F. (1958). The psychology of interpersonal relations. New York: Wiley.

Hertz, D.G. (1990). Trauma and nostalgia: New aspects of the coping of aging holocaust survivors. Israeli Journal of Psychiatry and Related Sciences, 27, 189-198.

Horberg, E. J., Oveis, C., \& Keltner, D. (2011). Emotions as moral amplifiers: An appraisal tendency approach to the influences of distinct emotions upon moral judgment. Emotion Review. In press.

Horberg, E. J., Oveis, C., Keltner, D., \& Cohen, A. B. (2009). Disgust and the moralization of purity. Journal of Personality and Social Psychology, 97, 963-976.

Hyman, I. E., \& Pentland, J. (1996). The role of mental imagery in the creation of false childhood memories. Journal of Memory and Language, 35, 101-117.

Jacob, P. \& Dupoux, E. (2008). A precursor of moral judgment in human infants? Current Biology, 8(5), R216-R218.

James, A. Jenks, C., \& Prout, A. (1998). Theorizing childhood. Oxford, U.K.: Blackwell. 
Jones, E. E., Rhodewalt, E, Berglas, S., \& Skelton, J. A. (1981). Effects of strategic selfpresentation on subsequent self-esteem. Journal of Personality and Social Psychology, $41,407-421$.

Kakavoulis, A. (1998). Aggressive and prosocial behavior in Greek children. International Journal of Early Years Education, 6(13), 343-351.

Kaplan, H.A. (1987). The psychopathology of nostalgia. Psychoanalytic Review, 74, 465-486.

Knafo, A., \& Plomim, R. (2006). Prosocial behavior from early to middle childhood: genetic and environmental influences on stability and change. Development Psychology, 42, 771-786.

Lane, I., \& Coon, R. (1972). Reward allocation in preschool children. Child Development, 43, 1382-1389.

Leventhal, G., \& Anderson, D. (1970). Self-interest and the maintenance of equity. Journal of Personality and Social Psychology, 15, 57-62.

Levine, L. J., Stein, N. L., \& Liwag, M. D. (1999). Remembering children's emotions: Sources of concordance and discordance between parents and children. Developmental Psychology, 35, 790-801.

Liljenquist, K., Zhong, C. B. \& Galinsky, A. D. (2008, August). Environmental cleanliness and the regulation of ethical behavior. In F. Gino (Chair), Environmental and outcome-based influences on unethical behavior. Paper presented at the Academy of Management, Anaheim, CA.

Liljenquist, K., Zhong, C. B. \& Galinsky, A. D. (2010). The smell of virtue: Clean scents promote reciprocity and charity. Psychological Science, 21, 381-383.

Loftus, E. F. (1979). Eyewitness testimony. Cambridge: Harvard University Press. 
Loftus, E. F., Donders, K., Hoffman, H. G., \& Schooler, J. W. (1989). Creating new memories that are quickly accessed and confidently held. Memory and Cognition, 17, 607-616.

Mackinnon, A., Jorm, A. F., Christensen, H., Korten, A. E., Jacomb, P. A., \& Rodgers, B. (1999). A short form of the Positive and Negative Affect Schedule: Evaluation of factorial validity and invariance across demographic variables in a community sample. Personality and Individual Differences, 27, 405-416.

Markus, H., \& Kunda, Z. (1986). Stability and malleability of the self-concept. Journal of Personality and Social Psychology, 51, 858-866.

Markus, H., \& Nurius, P. (1986). Possible selves. American Psychologist, 41, 954-969.

Markus, H., \& Ruvolo, A. (1989). Possible selves: Personalized representations of goals. In L. A. Pervin (Ed). Goal concepts in personality and social psychology (pp. 211-241). Hillsdale, NJ: Lawrence Erlbaum Associates, Inc.

Mazar, N., Amir, O., \& Ariely, D. (2008). The dishonesty of honest people: A theory of selfconcept maintenance. Journal of Marketing Research, 45, 633-644.

Messick, D. M., \& Bazerman, M. H. (1996). Ethical leadership and the psychology of decision making. Sloan Management Review, 9-22.

Miles, C. (1893). A study of individual psychology. American Journal of Psychology, 6, 534558.

Miller, P. A., \& Eisenberg, N. (1988). The relation of empathy to aggressive and externalizing/antisocial behavior. Psychological Bulletin, 103, 324-344.

Monin, B., \& Jordan, A.H. (2009). Dynamic moral identity: A social psychological perspective. Chapter 15 (pp.341-354) in D. Narvaez \& D. Lapsley (Eds), Personality, Identity, and Character: Explorations in Moral Psychology, Cambridge University Press. 
Neely, J. (1977). Semantic priming and retrieval from lexical memory: Roles of inhibitionless spreading activation and limited-capacity attention. Journal of Experimental Psychology: General, 106, 226-254.

Neisser, U. (1982). Snapshots or benchmarks? In U. Neisser (Ed.), Memory observed (pp. 4348). San Francisco: Freeman.

Neisser, U. (1988). Five kinds of self-knowledge. Philosophical Psychology, 1, 35-59.

Persson, G. E. B. (2005). Developmental perspectives on prosocial and aggressive motives in preschoolers' peer interactions. International Journal of Behavioral Development, 29, 8091.

Piliavin, J. A., \& Callero, P. L. (1991). Giving blood: The development of an altruistic identity. The Johns Hopkins University Press, USA.

Preacher, K. J., \& Hayes, A. F. (2004). SPSS and SAS procedures for estimating indirect effects in simple mediation models. Behavior Research Methods, Instruments, and Computers, $36,717-731$.

Robinson, J. A. (1986). Temporal reference systems and autobiographical memory. In D. C. Rubin (Ed.), Autobiographical memory (pp. 159-188). Cambridge, England: Cambridge University Press.

Robinson, J. A. (1992). First experience memories: Contexts and function in personal histories. In M. A. Conway, D. C. Rubin, H. Spinnler, \& W. A. Wagenaar (Eds.). Theoretical perspectives on autobiographical memory (pp. 223-239). Dordrecht, the Netherlands: Kluwer Academic.

Rozin, P., Lowery, L., Imada, S., \& Haidt, J. (1999). The CAD triad hypothesis: A mapping between three moral emotions (contempt, anger, disgust) and three moral codes 
(community, autonomy, divinity). Journal of Personality and Social Psychology, 76, $578-586$.

Rozin, P., Markwith, M., \& McCauley, C. (1994). Sensitivity to indirect contacts with other persons: AIDS aversion as a composite of aversion to strangers, infection, moral taint, and misfortune. Journal of Abnormal Psychology, 103495-103504.

Rozin, P., Millman, L., \& Nemeroff, C. (1986). Operation of the laws of sympathetic magic in disgust and other domains. Journal of Personality and Social Psychology, 50, 703-712.

Rubin, D. C. (Ed.) (1986). Autobiographical memory. Cambridge, England: Cambridge University Press.

Sanitoso, R., Kunda, Z., \& Fong, G. T. (1990). Motivated recruitment of autobiographical memories. Journal of Personality and Social Psychology, 59(2), 229-241.

Schnall, S., Benton, J., \& Harvey, S. (2008). With a clean conscience. Cleanliness reduces the severity of moral judgments. Psychological Science, 19(12), 1219-1222.

Schwartz, S. H. and Bilsky, W. (1990). Toward a theory of the universal content and structure of values: Extensions and cross cultural replications. Journal of Personality and Social Psychology, 58, 878-891.

Scott, S., \& Watson-Brown, L. (1997). The beast, the family and the little children. Trouble and Strife 36.

Sedikides, C., Wildschut, T., Arndt, J., \& Routledge, C.D. (2008). Nostalgia: Past, present, and future. Current Directions in Psychological Science, 17(5), 304-307.

Sherman, G. D., \& Clore, G. L. (2009). The color of sin: White and black are perceptual symbols of moral purity and pollution. Psychological Science, 20, 1019-1025. 
Sherman, S. J., Skov, R. B., Hervitz, E. F., \& Stock, C. B. (1981). The effects of explaining hypothetical future events: From possibility to probability to actuality and beyond. Journal of Experimental Social Psychology, 17, 142-158.

Shweder, R. A., Much, N. C., Mahapatra, M., \& Park, L. (1997). The "Big Three" of morality (autonomy, community, and divinity) and the "Big Three" explanations of suffering. In A. Brandt \& P. Rozin (Eds.), Morality and health (pp. 119-169). New York, NY: Routledge.

Tulving, E., Schacter, D. L., \& Stark, H. A. (1982). Priming effects in word-fragment completion are independent of recognition memory. Journal of Experimental Psychology: Learning, Memory and Cognition, 8, 336-342.

Twenge, J. M., Baumeister, R. F., DeWall, C. N., Ciarocco, N. J., \& Bartels, J. M. (2007). Social exclusion decreases prosocial behavior. Journal of Personality and Social Psychology, $92,56-66$.

Vaish, A., Carpenter, M., \& Tomasello, M. (2009). Sympathy through affective perspective taking and its relation to prosocial behavior in toddlers. Developmental Psychology, 45, 534-543.

Vess, M., Arndt, J., Routledge, C., Sedikides, C., \& Wildschut, T. (2008). Nostalgia as selfesteem resource. Unpublished data, University of Missouri.

Warneken, F. \& Tomasello, M. (2007). Helping and cooperation at 14 months of age. Infancy, 11(3), 271-294.

Warneken, F., Hare, B., Melis, A. P., Hanus, D., \& Tomasello, M. (2007). Spontaneous altruism by chimpanzees and young children. PLoS Biology, 5(7), 1414-1420. 
Watson, D., Clark, L. A., \& Tellegen, A. (1988). Development and validation of brief measures of Positive and Negative Affect: The PANAS Scales. Journal of Personality and Social Psychology, 54, 1063-1070.

Wheatley, T., \& Haidt, J. (2005). Hypnotically induced disgust makes moral judgments more severe. Psychological Science, 16, 780-784.

Wildschut, T., Sedikides, C., Arndt, J., \& Routledge, C.D. (2006). Nostalgia: Content, triggers, functions. Journal of Personality and Social Psychology, 91, 975-993.

Woodrow, C. (1999). Revisiting images of the child in early childhood education: Reflections and considerations. Australian Journal of Early Childhood, 24(4), 7-12.

Zahn-Waxler, C., Radke-Yarrow, M., \& King, R.A. (1979). Child rearing and children's prosocial initiations toward victims of distress. Child Development, 50, 319-330.

Zhong, C. B., \& Leonardelli, G. J. (2008). Cold and lonely: Does social exclusion literally feel cold? Psychological Science, 19(9), 838-842.

Zhong, C., \& Liljenquist, K. A. (2006). Washing away your sins: Threatened morality and physical cleansing. Science, 313, 1451-1452.

Zhou, X., Sedikides, C., Wildschut, T., \& Gao, D-G. (2008). Counteracting loneliness: On the restorative function of nostalgia. Psychological Science, 19, 1023-1029. 
Tables

Table 1

Coefficient Estimates for Regression Analyses (Experiment 3)

\begin{tabular}{|c|c|c|c|c|c|c|}
\hline & \multicolumn{3}{|c|}{ Moral purity } & \multicolumn{3}{|c|}{ Amount of money donated (in \$) } \\
\hline & B (SE) & B & $t$ & B (SE) & $\beta$ & $t$ \\
\hline Childhood memories ( $0=$ no, $1=y e s)$ & $.97(.29)$ & .44 & $3.24 * *$ & & & \\
\hline Moral purity prime $(0=$ no, $1=y e s)$ & $.83(.29)$ & .39 & $2.84 * *$ & & & \\
\hline Childhood memories X Prime & $-.88(.41)$ & -.37 & $-2.18^{*}$ & & & \\
\hline$r^{2}$ & & & $.13^{* *}$ & & & \\
\hline Childhood memories & & & & $.40(.23)$ & .21 & 1.74 \\
\hline Moral purity & & & & $.40(.12)$ & .46 & $3.34 * *$ \\
\hline Moral purity prime & & & & $.11(.23)$ & .06 & .049 \\
\hline Childhood memories X Prime & & & & $-.42(.30)$ & -.20 & -1.39 \\
\hline Moral purity X Prime & & & & $.22(.15)$ & .24 & 1.48 \\
\hline$r^{2}$ & & & & & & $.46^{* * *}$ \\
\hline
\end{tabular}

Notes: $* p<.05, * * p<.01, * * * p<.001$

Table 2

Analysis of Simple Effects (Experiment 3)

\begin{tabular}{lccccc}
\hline \multicolumn{2}{c}{ Moderator: } & \multicolumn{2}{c}{ Stage } & \multicolumn{3}{c}{ Effect } \\
\cline { 2 - 6 } Prime & First & Second & Direct & Indirect & Total \\
Neutral (0) & $.93^{*}$ & $.40^{*}$ & .40 & $.37^{*}$ & $.77^{*}$ \\
Moral purity (1) & .05 & $.62^{*}$ & -0.02 & .03 & .01 \\
Differences & $.88^{*}$ & -.22 & .42 & .34 & $.76^{*}$ \\
\hline
\end{tabular}

Notes: Tests of differences for the first stage, second stage, and direct effect are equivalent to tests of the corresponding coefficients reported in Table 1. Tests of differences for the indirect and total effect were based on $95 \%$ bias-corrected confidence intervals derived from bootstrap estimates. 


\section{Figures}

Figure 1. Percentage of participants who donated by condition, Experiment 3

\section{Figure 1}

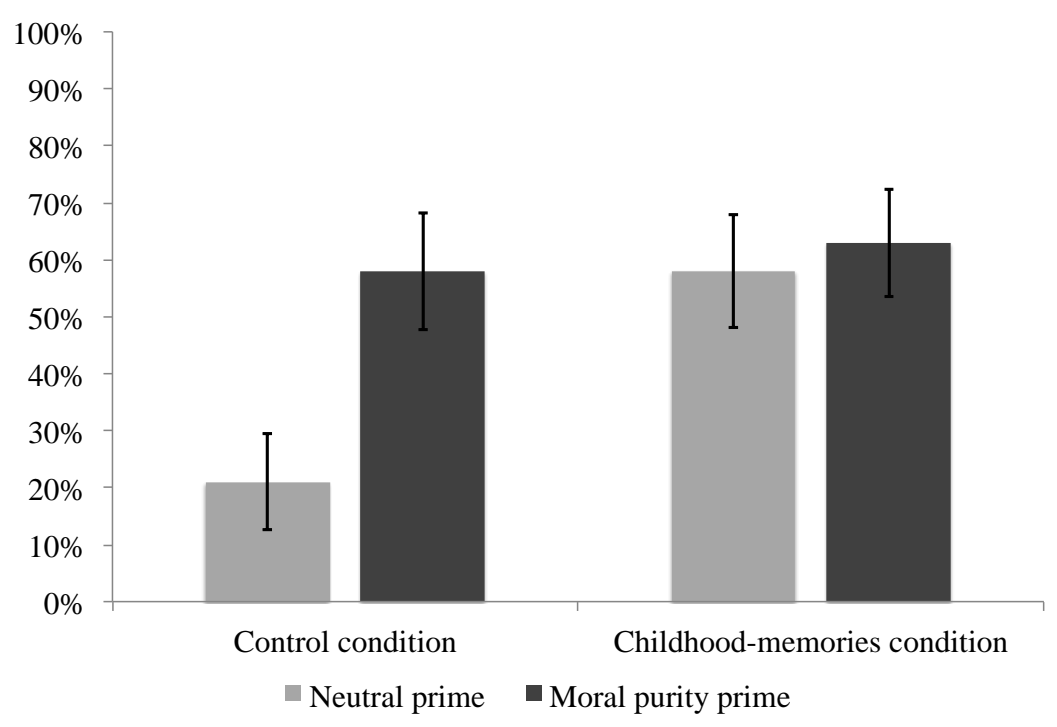

